\title{
Atividades digitais e a construção dos conceitos de proporcionalidade: uma análise a partir da Teoria dos Campos Conceituais
}

\author{
Leandra Anversa Fiorezze \\ Orientador: Dante Augusto Couto Barone \\ Coorientador: Marcus Vinicius de Azevedo Basso \\ Data da defesa: 13 de janeiro de 2010
}

Nesta tese, foi desenvolvida uma investigação, utilizando, principalmente, atividades digitais relacionadas com a aprendizagem dos conceitos de proporcionalidade. A base para analisar as construções conceituais dos alunos é a Teoria dos Campos Conceituais, de Gerard Vergnaud. Esta teoria é considerada cognitivista e busca compreender os processos de conceitualização, situando e estudando as filiações e rupturas entre conhecimentos do ponto de vista de seu conteúdo conceitual. Além disso, esta teoria trabalha com a noção de conhecimento a partir das habilidades e informações expressas pelas crianças e adolescentes. Para garantir uma maior abrangência de situações envolvendo o campo conceitual das estruturas multiplicativas e da proporcionalidade, selecionouse os softwares Régua e Compasso, planilha eletrônica, geoplano, dois objetos de aprendizagem criados pelo grupo de pesquisa RIVED/UNIFRA, um vídeo Matemática na Vida: Razão e Proporção, do portal Domínio Público e objetos materiais como maquetes, molas, moedas, folhas de papel. Para o acompanhamento das aulas e permitir a socialização e a interação por meio de comentários, foi criado um Blog no Wordpress. A metodologia escolhida foi a Engenharia Didática, que valoriza as relações de dependência entre a dimensão teórica e a prática da pesquisa. Os sujeitos da pesquisa foram alunos da oitava série de uma escola municipal, situada na zona rural do município de Silveira Martins, RS. Os resultados demonstram potenciais contribuições das atividades digitais para o desenvolvimento das estruturas multiplicativas e da proporcionalidade. Verificou-se que as duplas de alunos conseguiram maior coerência no uso de modelos explicativos em diferentes situações, interpretando as situações e resolvendo-as de forma a explicitar seus conhecimentos, utilizando a linguagem natural ou simbólica e estabelecendo relações com as novas situações a vencer. Nesse sentido, os teoremas em ação e os conceitos em ação se tornaram mais claros, atingindo um novo patamar, em que os conceitos espontâneos evoluíram para conceitos científicos. Há de se destacar que o professor tem um papel importante no planejamento, na escolha das atividades e no nível de profundidade abordado, devendo levar em conta o desenvolvimento cognitivo dos sujeitos, pois isto é um fator que poderá motivar ou não o aluno a aprender a aprender, ou seja, a querer ser o autor do seu próprio processo de construção de conhecimento.

Palavras-chave: Aluno. Ambiente de aprendizagem. Ambiente digital. Engenharia didática. Ensino fundamental. Matemática. Proporcionalidade. Software educacional. Teoria dos campos conceituais. Vergnaud, Gérard.

Referência:

FIOREZZE, Leandra Anversa. Atividades Digitais e a Construção dos Conceitos de Proporcionalidade: uma análise a partir da Teoria dos Campos Conceituais. Orientador: Dante Augusto Couto Barone. Coorientador: Marcus Vinicius de Azevedo Basso.Tese (Doutorado) - Programa de PósGraduação em Informática na Educação, CINTED/UFRGS, 2010, Porto Alegre, BR-RS. 